\title{
Bacteriological Profile of CSOM and Antibiotic Susceptibility Pattern of Aerobic Isolates in a Tertiary Care Hospital of Central India
}

\author{
Vikas Jain $^{1 *}$, Swati Jain ${ }^{2}$ and Rajesh Kumar Shah ${ }^{1}$ \\ ${ }^{1}$ Department of Microbiology, ${ }^{2}$ Department of Community Medicine, \\ RKDF Medical College\& RC, Bhopal, Madhya Pradesh, India \\ *Corresponding author
}

\section{Keywords}

Bacteriological profile, CSOM,

Antibiotic

Susceptibility

pattern,

Cephalosporins,

Amoxycillin

Article Info

Accepted:

14 December 2018

Available Online:

10 January 2019

\section{A B S T R A C T}

Chronic Suppurative Otitis Media (CSOM) is one of the most common diseases of the ear of all age groups. It is a destructive and persistent disease with irreversible outcome and a major health problem in developing nations with low socio-economic civilization because of malnutrition, overcrowding, poor hygiene and inadequate health care and laboratory facilities. Aerobic and anaerobic bacteria are the important causative agents of CSOM. Hence this study was conducted to identify the common bacterial isolates from patients diagnosed with CSOM at tertiary center in central India and to determine the antibiotic sensitivity pattern of aerobic bacterial isolates. A total of 157 patients were enrolled and processed for isolation of bacterial isolates using standard microbiological tests with sensitivity pattern. SPSS software 20 and MS Microsoft Excel 2007 was used for statistical analysis. Bacterial cultures were positive in 133 cases out of which $126(94.75 \%)$ were aerobes and $7(5.25 \%)$ were anaerobes. Antimicrobial susceptibility testing of the aerobic bacterial isolates was performed by disc diffusion method according to clinical laboratory standards institute guidelines. The aerobic bacterial isolates were mostly sensitive to commonly used antimicrobials like $3^{\text {rd }}$ generation cephalosporins, Amoxycillin + Clavulanic acid, Amikacin and Ciprofloxacin. Evidence based judicial treatment and appropriate use of antimicrobials will ensure \& reduce the resistance to antimicrobials and the cost of treatment.

\section{Introduction}

Chronic Suppurative Otitis Media (CSOM) is a chronic inflammation of the middle ear and mastoid cavity, which presents with recurrent otorrhoea through a tympanic perforation. Due to the perforated tympanic membrane, microorganisms can enter into the middle ear via the external ear canal. Infection of the middle ear mucosa subsequently results in ear discharge. ${ }^{1}$ Incidence of this disease is higher in developing countries especially among low socio-economic society because of malnutrition, overcrowding, poor cleanliness, insufficient health care, and recurrent upper respiratory tract infection. ${ }^{2}$ It is a huge public health problem, and India is one of the countries with highest CSOM prevalence (> $4 \%$, 
WHO 2004). It is a common cause of hearing impairment and can occasionally lead to fatal intracranial infection. Over 50 percent of the cases are caused by bacteria. ${ }^{3}$ Most common isolates found in CSOM are Aerobic bacteria (Staphylococcus aureus, Staphylococcus aureus, Proteus mirabilis, Klebsiella pneumoniae, Escherichia coli etc.), anaerobic bacteria (Bacteroids, Peptostreptococcus, Peptococcus. etc.) but distribution of these isolates differ in various geographical areas. ${ }^{4}$

Topical preparations containing antibiotics and steroids, to reduce otorrhea and to provide local anti-inflammatory effect are the bases of medical management of chronic otitis media $^{5,6}$. The knowledge of bacterial etiology of CSOM is very important for the clinicians for appropriate management of the cases, to prevent or minimize the occurrence of complications and prevent emergence of resistant strains ${ }^{7}$

The present study was conducted to isolate aerobic as well as the anaerobic bacteria involved in the CSOM and the antibiotic susceptibility pattern of aerobic bacteria. Study of susceptibility pattern of anaerobic bacteria was not included in this study.

\section{Materials and Methods}

This study was performed in the department of Microbiology, People's college of Medical Sciences and Research Centre Bhopal from NOV 2012-APR 2014. Ethical committee approval was obtained before starting the study.

After written informed consent, ear discharge from clinically diagnosed patients was collected and processed in Microbiology department. Three sterile swabs were used for collecting ear discharge. The 1st swab was used to make a smear on a clean glass slide for direct smear examination by Gram's stain and
Ziehl-Neelsen stain. $2^{\text {nd }}$ and $3^{\text {rd }}$ swab was processed for the isolation of aerobic and anaerobic bacteria. $2^{\text {nd }}$ Swab was used to inoculate MacConkey's agar (MA) and Blood agar plates. All plates are incubated aerobically at $37^{\circ} \mathrm{C}$ and evaluated at 24 hours, 48 hours and 72 hours and the plates are discarded if there is no growth. The specific identification of bacterial pathogens is done based on microscopic morphology, staining characteristics, cultural and biochemical properties using standard laboratory procedures. $8,9,10$

Under aseptic precaution samples for the anaerobic culture were collected in $3^{\text {rd }}$ swab and inoculated in Robertson's cooked meat (RCM) broth. From RCM inoculation was done on two plates each of blood agar (Columbia agar with 5\% sheep blood by Himedia) and two selective blood agar (Vancomycin / Kanamycin (V/K) blood agar, Neomycin/ Vancomycin blood agar) ${ }^{9}$. Primary sensitivity test was done by placing metronidazole disc $(5 \mu \mathrm{g})$ at the junction of secondary and tertiary streaking area, opposite to primary well of inoculation.

One agar plate was incubate aerobically, and rest of the plates were incubated anaerobically by using anaerobic jar (3.5 litre from Himedia) with anaerogas Pack (3.5L from Himedia). After 24 hours one blood agar plate and one selective blood agar plate were checked, remaining plates were left for 48 hours. Plates were examined for typical colonies. Reincubation of plates for 48 hours was done for slow growers. After incubation, zone of inhibition around the metronidazole disk was examined. An aero-tolerance test on Chocolate agar (CA) was set up to rule out facultative anaerobes.

Identification of anaerobes was done by using rapid ID 32 A (biomerieux India) and ATB system. As per manufacturer's instructions 
one well isolated colony was sub-cultured on a Columbia agar with $5 \%$ sheep blood. Incubation was done for 24 hours at $37^{\circ} \mathrm{C}$ in anaerobic conditions. Inoculum was prepared by mixing a growth obtained from blood agar with sterile distilled water with turbidity equivalent to $4 \mathrm{McF}$ arland measure with the DENSIMAT. With the help of pipette $55 \mu 1$ of the suspension, dispensed into each cupule of the strip. Then strip was covered with lid and incubate at $37^{\circ} \mathrm{C}$ for 4 hours in aerobic conditions. Strip was placed in the ATB system for identification of anaerobes.

Antimicrobial susceptibility of the aerobic isolates was performed on Mueller Hinton Agar plates by Kirby-Bauer disc diffusion method according to the Clinical Laboratory Standards Institute (CLSI) guidelines. ${ }^{11}$ Data was compiles and statistical analysis was performed by using Statistical Package for the Social Sciences (SPSS) software 20 and MS Microsoft Excel 2007.

\section{Results and Discussion}

Among 157 studied cases 92(58.60\%) cases were males and $65(41.40 \%)$ cases were females. Age of the subjects in the study group varies from 1 year to 73 years. Maximum patients of CSOM belong to age group 11-20 years which was 37 (23.57\%) and least cases of CSOM which was $13(8.28 \%)$ found in age group 41-50 years (Table 1).

Out of 157 samples, 133 were culture positive and 24 were culture negative. The results of bacteriological studies on the 133 cases showed that positive aerobic bacterial cultures were obtained in $126(94.75 \%)$ cases while positive anaerobic cultures were obtained in only $7(5.25 \%$ ) cases (Table 2 ).

Out of 126 aerobes Staphylococcus aureus was most commonly isolated organism 62(49.20\%) followed by Staphylococcus aureus 33(26.20\%). Among 7 anaerobic isolates Fusobacterium spp was most common $3(42.86 \%)$ followed by bacteroides $2(28.57 \%)$ and Peptostreptococcus 2(28.57\%) (Table 3).

Table 4 and 5 shows the antibiotic sensitivity pattern of various aerobic bacteria isolated from CSOM cases. Out of 126 (100.00\%) isolates $109(86.50 \%)$ were sensitive to Cefotaxime, $108(85.71 \%)$ were sensitive to Amoxyclav, 94 (74.60\%) were sensitive to Amikacin, $60(47.62 \%)$ were sensitive to Ciprofloxacin, $55(43.65 \%)$ were sensitive to Gentamicin and $51(40.47 \%)$ were sensitive to Cotrimoxazole. that Cefotaxime had highest sensitivity $53(48.62 \%)$ for Staphylococcus aureus followed by Amoxyclav 52 (48.14\%) and Amikacin 42 (44.68\%). Antibiotic susceptibility pattern of anaerobes was not included in the study

For prescribing appropriate treatment of CSOM Identification of causative organisms is important as a wide range of Organisms are isolated in CSOM. Local damage to the middle ear is often seen in CSOM patients as the organisms may spread to adjacent structures near the ear or middle ear itself. Intracranial and extra-cranial complications may develop in untreated cases of CSOM. Early bacteriological diagnoses of all cases will ensure accurate and appropriate therapy. This study was conducted for the assessment of aerobic and anaerobic bacteriological profile of CSOM, with antimicrobial susceptibility testing of the aerobic isolates. The results are compared with the other studies and discussed as follows.

In our study out of total 133 positive case, males $78(58.65 \%)$ were more affected than females $55(41.35 \%)$. This finding is in consonance with the study conducted by Ahmed et al., ${ }^{12}$ who showed $(57.29 \%)$ male and $(42.70 \%)$ female cases out of 192 $(100.00 \%)$ cases in their study. 
Table.1 Age wise distribution of study population

\begin{tabular}{|c|c|c|}
\hline Age & No. of patients & Percentage (\%) \\
\hline 0-10 years & 36 & 22.93 \\
\hline $\mathbf{1 1 - 2 0}$ years & 37 & 23.57 \\
\hline $\mathbf{2 1 - 3 0}$ years & 27 & 17.19 \\
\hline 31-40 years & 23 & 14.65 \\
\hline 41-50 years & 13 & 8.28 \\
\hline >50 years & 21 & 13.38 \\
\hline Total & $\mathbf{1 5 7}$ & $\mathbf{1 0 0 . 0 0}$ \\
\hline
\end{tabular}

Table.2 Distribution of isolates among study population

\begin{tabular}{|c|c|c|}
\hline Types of isolates & Frequency & Percentage (\%) \\
\hline Aerobes & 126 & 80.25 \\
\hline Anaerobes & 7 & 4.45 \\
\hline No organism & 24 & 15.30 \\
\hline Total & $\mathbf{1 5 7}$ & $\mathbf{1 0 0}$ \\
\hline
\end{tabular}

Table.3 Distribution of various bacterial isolates in study population

\begin{tabular}{|c|c|c|c|}
\hline \multicolumn{1}{|c|}{} & Organism & Frequency & Percentage (\%) \\
\hline \multirow{4}{*}{ Aerobic } & Staphylococcus aureus & 62 & 49.20 \\
\cline { 2 - 4 } Isolates & Staphylococcus aureus & 33 & 26.20 \\
\cline { 2 - 4 } & Klebsiella species & 10 & 7.94 \\
\cline { 2 - 4 } & Escherichia coli & 09 & 7.14 \\
\cline { 2 - 4 } & Streptococcus Pyogenes & 06 & 4.76 \\
\cline { 2 - 4 } & Citrobacter freundii & 04 & 3.17 \\
\cline { 2 - 4 } & Acinetobacter species & 02 & 1.59 \\
\cline { 2 - 4 } & Total & $\mathbf{1 2 6}$ & $\mathbf{1 0 0 . 0 0}$ \\
\hline \multirow{3}{*}{ Anaerobic } & Bacteroids species & 03 & 42.86 \\
\cline { 2 - 4 } Isolates & Fusobacterium species & 02 & 28.57 \\
\cline { 2 - 4 } & Peptostreptococcus & 02 & 28.57 \\
\cline { 2 - 4 } & Total & $\mathbf{0 7}$ & $\mathbf{1 0 0 . 0 0}$ \\
\hline
\end{tabular}

Table.4 Antibiotic sensitivity pattern for Aerobic bacterial isolates

\begin{tabular}{|c|c|c|}
\hline Antibiotic & Sensitive N(\%) & Total N (\%) \\
\hline Amikacin & $94(74.60)$ & $126(100)$ \\
\hline Ciprofloxacin & $60(47.62)$ & $126(100)$ \\
\hline Amoxyclav & $108(85.71)$ & $126(100)$ \\
\hline Gentamicin & $55(43.65)$ & $126(100)$ \\
\hline Cefotaxime & $109(86.50)$ & $126(100)$ \\
\hline Cotrimoxazole & $51(40.47)$ & $126(100)$ \\
\hline
\end{tabular}


Table.5 Sensitivity pattern of aerobic bacterial isolates in CSOM

\begin{tabular}{|c|c|c|c|c|c|c|c|}
\hline \multirow[t]{2}{*}{ Isolates } & \multirow{2}{*}{$\begin{array}{l}\text { No. of } \\
\text { isolates } \\
\mathbf{N}(\%)\end{array}$} & \multicolumn{6}{|c|}{ Type of Antibiotics N (\%) } \\
\hline & & $\mathbf{A K}$ & CIP & CTX & GEN & $\mathbf{A M C}$ & COT \\
\hline $\begin{array}{c}\text { Pseudomonas } \\
\text { aeruginosa }\end{array}$ & $\begin{array}{c}62 \\
(49.21)\end{array}$ & $\begin{array}{c}42 \\
(44.68)\end{array}$ & $\begin{array}{c}31 \\
(51.66)\end{array}$ & $\begin{array}{c}53 \\
(48.62)\end{array}$ & $\begin{array}{c}22 \\
(40.00)\end{array}$ & $\begin{array}{c}52 \\
(48.14)\end{array}$ & $\begin{array}{c}19 \\
(37.25)\end{array}$ \\
\hline $\begin{array}{c}\text { Staphylococcus } \\
\text { aureus }\end{array}$ & $\begin{array}{c}33 \\
(26.19)\end{array}$ & $\begin{array}{c}30 \\
(31.91)\end{array}$ & $\begin{array}{c}20 \\
(33.33)\end{array}$ & $\begin{array}{c}32 \\
(29.35)\end{array}$ & $\begin{array}{c}19 \\
(34.55)\end{array}$ & $\begin{array}{c}31 \\
(28.70)\end{array}$ & $\begin{array}{c}17 \\
(33.33)\end{array}$ \\
\hline $\begin{array}{c}\text { Klebsiella } \\
\text { species }\end{array}$ & $\begin{array}{c}10 \\
(7.93)\end{array}$ & $\begin{array}{c}8 \\
(8.51)\end{array}$ & $\begin{array}{c}4 \\
(6.67)\end{array}$ & $\begin{array}{c}7 \\
(6.42)\end{array}$ & $\begin{array}{c}7 \\
(12.72)\end{array}$ & $\begin{array}{c}9 \\
(8.33)\end{array}$ & $\begin{array}{c}6 \\
(11.76)\end{array}$ \\
\hline $\begin{array}{c}\text { Escherichia } \\
\text { coli }\end{array}$ & $\begin{array}{c}09 \\
(7.14)\end{array}$ & $\begin{array}{c}5 \\
(5.31)\end{array}$ & $\begin{array}{c}2 \\
(3.33)\end{array}$ & $\begin{array}{c}9 \\
(8.26)\end{array}$ & $\begin{array}{c}5 \\
(9.09)\end{array}$ & $\begin{array}{c}8 \\
(7.40)\end{array}$ & $\begin{array}{c}5 \\
(9.80)\end{array}$ \\
\hline $\begin{array}{l}\text { Streptococcus } \\
\text { Pyogenes }\end{array}$ & $\begin{array}{c}06 \\
(4.76)\end{array}$ & $\begin{array}{c}5 \\
(5.31)\end{array}$ & $\begin{array}{c}2 \\
(3.33)\end{array}$ & $\begin{array}{c}3 \\
(2.75)\end{array}$ & $\begin{array}{c}0 \\
(0.00)\end{array}$ & $\begin{array}{c}4 \\
(3.70)\end{array}$ & $\begin{array}{c}0 \\
(0.00)\end{array}$ \\
\hline $\begin{array}{l}\text { Citrobacter } \\
\text { freundii }\end{array}$ & $\begin{array}{c}04 \\
(3.17)\end{array}$ & $\begin{array}{c}4 \\
(4.25)\end{array}$ & $\begin{array}{c}1 \\
(1.67)\end{array}$ & $\begin{array}{c}3 \\
(2.75)\end{array}$ & $\begin{array}{c}2 \\
(3.64)\end{array}$ & $\begin{array}{c}2 \\
(1.85)\end{array}$ & $\begin{array}{c}4 \\
(7.84)\end{array}$ \\
\hline $\begin{array}{l}\text { Acinetobacter } \\
\text { species }\end{array}$ & $\begin{array}{c}02 \\
(1.59)\end{array}$ & $\begin{array}{c}0 \\
(0.00)\end{array}$ & $\begin{array}{c}0 \\
(0.00)\end{array}$ & $\begin{array}{c}2 \\
(1.83)\end{array}$ & $\begin{array}{c}0 \\
(0.00)\end{array}$ & $\begin{array}{c}2 \\
(1.85)\end{array}$ & $\begin{array}{c}0 \\
(0.00)\end{array}$ \\
\hline Total & $\begin{array}{c}126 \\
(100.00)\end{array}$ & $\begin{array}{c}94 \\
(74.60)\end{array}$ & $\begin{array}{c}60 \\
(47.62)\end{array}$ & $\begin{array}{c}109 \\
(86.50)\end{array}$ & $\begin{array}{c}55 \\
(43.65)\end{array}$ & $\begin{array}{c}108 \\
(85.71)\end{array}$ & $\begin{array}{c}51 \\
(40.47)\end{array}$ \\
\hline
\end{tabular}

The male predominance may be because of males are more actively involved in outdoor activities, hence more likely to be exposed to contaminated environment. ${ }^{13}$

In the present study the age ranged from less than 1 year to more than 50 years. In this study the maximum number of cases were found in the age group of 11-20 years 37 $(23.57 \%)$ followed by $0-10$ years 36 $(22.93 \%)$. These findings were correlated with a study conducted by Akinpelu and Amusa in their study of $160 \quad(100.00 \%)$ patients the maximum number of patients was in the age group of $0-10$ years $69(43.00 \%) .{ }^{14}$

The most common organism isolated in the present study was Staphylococcus aureus 62 (42.17\%) followed by Staphylococcus aureus 44(29.93\%). These findings were in consistency with a study conducted by workers like Hiremath et al., (2001) ${ }^{15}$ and Loy (2002). ${ }^{16}$ The most common anaerobe isolated in present study was Bacteroids spp $3(42.86 \%)$ followed by Fusobacterium spp. 2(28.57\%) and Peptostreptococcus 2(28.57\%). Geeta found $45.61 \%$ Peptostreptococcus followed by bacteroids $17.54 \%$ and Fusobacterium $7 \%$ in their study. ${ }^{17}$ Prakash et al., isolated $8(11.59 \%)$ Bacteroids species out of $69(100.00 \%)$ anaerobes in their study ${ }^{18}$. Kusuma Bai et al., found 13 (28.26\%) Peptostreptococcus among 46(100.00\%) anaerobes in their study. 19

Antibiotic sensitivity was carried out for 126 aerobic isolates by Kirby-Bauer disc diffusion method by using antibiotic discs. In the present study $109(86.50 \%)$ of organisms were sensitive to Cefotaxime, followed by Amoxyclav 108(85.71\%), Amikacin 94 (74.60\%), Ciprofloxacin $60 \quad(47.62 \%)$, Gentamicin 55 (43.65\%), Cotrimaxazole $51(40.47 \%)$. The most effective drugs in the present study are Cefotaxime, Amoxyclav and 
Amikacin. Similar sensitivity pattern was reported by Shyamala and Reddy ${ }^{20}$. However Singh et al., have found Ciprofloxacin as the most effective drug. ${ }^{21}$

This study was conducted with the aim of identification of causative agents associated with ear infections especially in an environment where antibiotics are commonly abused. Based on the findings from this study, it is therefore recommended that treatment of ear infection is better done when the causative agents as well as the drug sensitivity patterns are known and properly administered. Also the role of anaerobes should be studied. This will enhance the chances of better treatment and reduce the burden of the infection on the patients and reduce the cost of treatment.

It can be concluded that a variety of bacteria are responsible for CSOM with predominance of Staphylococcus aureus followed by Staphylococcus aureus, Klebsiella species, Escherichia coli and Streptococcus pyogenes. The antibiotic susceptibility testing showed Cefotaxime as the most effective drug followed by Amoxyclav, Amikacin, Ciprofloxacin, Gentamicin and cotrimoxazole.

\section{References}

1. Yousuf A, Malik M, Shamas IU, Beigh Z, Kumari S, Pampori PRA. Bacteriological profile of ear discharge and their antibiotic sensitivity in chronic suppurative otitis media in Kashmir, India. Bangla J Med Sci., 2012; 11(03): 212-216

2. Kumar H, Seth S. Bacterial and fungal study of 100 cases of chronic suppurative otitis media. J Clin Diagn Res 2011; 5: 1224-7.

3. Yang JA, Kim JY, Yoon YK, Kim S, Park DW, Sohn JW et al., Y Epidemiological and genetic characterization of MRSA isolates from the ear discharge of outpatients with CSOM. J Korean Med Sci. 2008; 23: 762-766.

4. Anwar-us-salam, Abid SH, Abdulla EM. Suppurative otitis in Karachi: An audit of 510 cases. Pak J Otolaryn 1997; 13: 66-9.

5. Youngs R (1998) Chronic suppurative otitis media. In: Ludman $\mathrm{H}$, Wright $\mathrm{T}$ (eds) Diseases of the ear, Chapter 27-29, 6th edn. Arnold Publishers, London, pp. 374-415.

6. Dhingra PL, Dhingra S (2010) Cholesteatoma and chronic otitis media. In: Diseases of Ear, Nose and Throat, Chapter 11, 5th edn. Elsevier, New Delhi, pp 75-83.

7. Prakash M, Lakshmi K, Anuradha S, Swathi Gn. Asian J Pharm Clin Res. 2013; Vol 6, Suppl 3:210-212.

8. Betty A Forbes, Daniel F Sahm, Alice Weissfeld. Bailey and Scott Diagnostic Microbiology. 12th edition: Elsevier 2007; pp. 832-42.

9. Duiguid JP, Collee JG, Fraser AG. Laboratory strategy in the diagnosis of infective syndromes. In: Mackie and McCartney Practical Medical Microbiology (14th Edition), Churchill Livingstone, London 2004.

10. Koneman EW, Allen Stephen D. Colour Atlas and Textbook of diagnostic microbiology. 5th edition. Philadelphia: Lippincott; 1997.

11. Clinical and Laboratory Standard Institute, 2012. Performance standards for antimicrobial susceptibility testing. Clinical and Laboratory Standards Institute, Wayne. 24th Informational Supplement.

12. Ahmed A, Usman J, Hashim R. Isolates from chronic suppurative otitis media and their antimicrobical sensitivity. Pak Armed Forces Med J 1999; 49: 82-5.

13. 12. Agarwal S.R. Jain A.K. Goyal R. B et al., -Clinicomycological study of 
otomycosis with special reference to silent tympanic membrane perforation. Ind. J. Otol. 2001, Vol. 7, No. 2, 49-52

14. OV Akinpelu et al., Challenges in Management of chronic suppurative Otitis media in a developing country. The Journal of Laryngology and Otology 2008; 122: 16-20.

15. Hiremath SL, Kanta RC, Yeshwanathrao M, Vasantha Kumar CM. Aerobic bacterial isolates of CSOM and their antibiotic sensitivity pattern. The Indian Practitioner 2001; 54(7): 486-489.

16. Loy AHC, Tan AL, Lu PKS. Microbiology of chronic suppurative otitis media in Singapore. Singapore Med J 2002; 43(6): 296-299.

17. Geeta S. H. "Study of Aerobes, Anaerobes \& Fungi in CSOM in a Referral Hospital of Bangalore Rural". Journal of Evolution of Medical and Dental Sciences 2014; Vol. 3, Issue 23, Pp: 6297-6303
18. Prakash R, Juyal D, Negi V, Pal S, Adekhandi S, Sharma M, Sharma N. Microbiology of chronic suppurative otitis media in a tertiary care setup of Uttarakhand State, India. N Am J Med Sci 2013; 5(4): 282-87.

19. Kusuma Bai S, Venkateswarlu K, Bala Krishna, Ashokreddy, Prasad Rao N. Study of bacteriology in chronic suppurative otitis media. International Journal of Medical Research \& Health Sciences 2013; 2: 510-13.

20. Shyamala R, Reddy PS. The study of bacteriological agents of chronic suppurative otitis media- aerobic culture and evaluation. J. Microbiol Biotech Res 2012; 2: 152-162.

21. Singh AH, Basu R, Venkatesh A. Aerobic bacteriology of Chronic Suppurative otitis media in Rajahmundry, Andhra Pradesh, India. Biology \& Medicine Journal 2012; 4: 73-79.

\section{How to cite this article:}

Vikas Jain, Swati Jain and Rajesh Kumar Shah. 2019. Bacteriological Profile of CSOM and Antibiotic Susceptibility Pattern of Aerobic Isolates in a Tertiary Care Hospital of Central India. Int.J.Curr.Microbiol.App.Sci. 8(01): 2240-2246. doi: https://doi.org/10.20546/ijcmas.2019.801.234 